\title{
Preservation of Sugarcane Juice Using Herbal Clarificant
}

\author{
Mst. Kohinoor Begum, Md. Shamsul Arefin, Md. Shariful Islam, Md. Jahirul Islam
}

Bangladesh Sugarcane Research Institute, Pabna, Bangladesh

\section{Email address:}

kohinoorsamia@yahoo.com (Mst. K. Begum)

\section{To cite this article:}

Mst. Kohinoor Begum, Md. Shamsul Arefin, Md. Shariful Islam and Md. Jahirul Islam. Preservation of Sugarcane Juice Using Herbal Clarificant. International Journal of Nutrition and Food Sciences. Vol. 4, No. 5, 2015, pp. 530-534. doi: 10.11648/j.ijnfs.20150405.13

\begin{abstract}
An experiment was carried out at Physiology and Sugar Chemistry Laboratory of Bangladesh Sugarcane Research Institute Ishurdi, Pabna, Bangladesh during 2013-2014 to determine the self life of sugarcane juice without adding any preservatives. Sugarcane varieties Isd 34, Isd 35, Isd 36, Isd 37 and Isd 38 were used for collection of juice and juice were collected in the month of September, October, November, December, January, February and March. Juice collected in the month of December and January showed the highest shelflife by using Mucilage substances of ladies finger (Hibiscus esculentus Linn) as a clarificant. Juice collected in the month of December, January showed highest self life due to presence of lower reducing sugar and highest percentage of sucrose.
\end{abstract}

Keywords: Sugarcane Juice, Preservation Technique, Clarificant, Self Life

\section{Introduction}

Sugarcane is an important industrial crop cultivated in tropical and subtropical regions of the world. Sugarcane has been used as a sweetener for millennia and today refined sugar is used in copious quantities to supplement the natural sugar (fructose) found in fruits and vegetables (Phanikumar, 2011). It possesses therapeutic value (Banerji et al., 1997).

Sugarcane juice is commonly used as a delicious drink in both urban and rural areas. Sugarcane juice of $100 \mathrm{ml}$ provides $40 \mathrm{Kcal}$ of energy, $10 \mathrm{mg}$ of iron and $6 \mu \mathrm{g}$ of carotene (Parvathy, 1983). Sugarcane juice is rich in enzyme and has many medicinal properties. It contains water $(75 \%-85 \%)$, reducing sugar $(0.3-3.0 \%)$, non-reducing sugar (10-21\%) (Swaminathan, 1995). Sugarcane juice is a great preventive and healing source for sore throat, cold and flu. It has a low glycemic index which keeps the body healthy. Even the diabetic can enjoy this one sweet drink without fear. It is because it has no simple sugars. It hydrates the body quickly when exposed to prolong heat and physical activity. It is excellent substitutes for aerated drinks and cola; it refreshes and energizes the body instantly as it is rich in carbohydrates. Sugarcane juice is also a popular drink in Bangladesh, but the cane juice is prepared in a unhygienic way. If the cane juice is collected, preserved in a hygienic way then they can be sold after short / long times preservation. On the other hand, it will meet up the nutritional problem of our large population.

In general sugarcane juice is spoiled quickly by the presence of simple sugars. The sugarcane juice can be introduced as delicious beverages by preventing the spoilage of juice with appropriate method. Biodegradation is caused by microorganisms mainly Leuconostoc sp. (L. mesenteroides and L. dextranium) also takes place. Soon after the harvest of sugarcane; endogenous invertase enzyme is activated and acts as a cause of deterioration. These organisms convert sucrose into polysaccharides, such as dextran. Besides, loss of sucrose, the presence of dextran even in very small amount creates problem of filtration, clarification, crystallization and alters the shape of sugar crystals thereby affecting the quality of sugar (Krishnakumar and Devadas, 2006).

Considering these facts, the present study has been planned to establish a protocol for preservation of sugarcane juice without adding any preservatives.

\section{Materials and Methods}

Many commercial juices are filtered to remove fiber. Common methods for preservation and processing of fruit juices include canning, pasteurization, freezing, evaporation, drying and addition of preservatives. A different method was followed for preservation of cane juice. 


\subsection{Collection of Sugarcane Juice}

Six sugarcane varieties viz. Isd 34, Isd 36, Isd 37, Isd

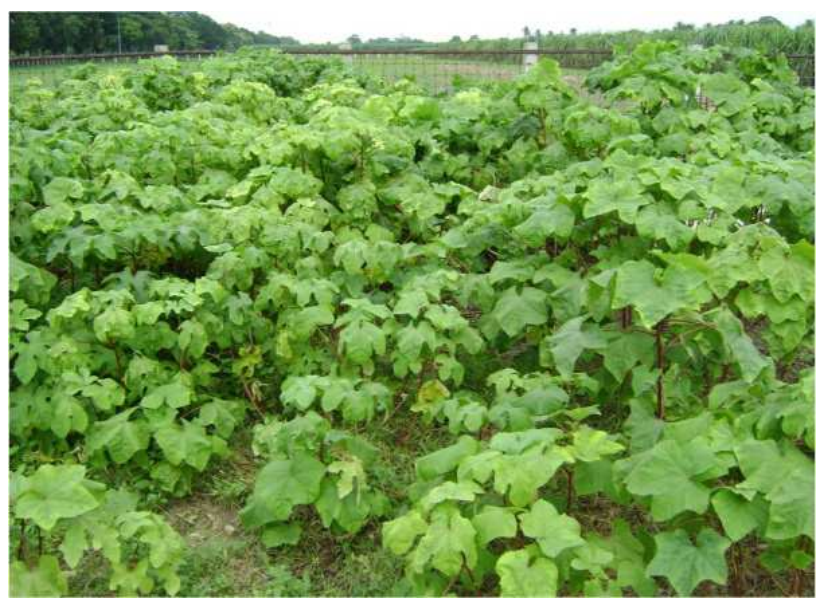

Fig. 1. Ladies finger garden.

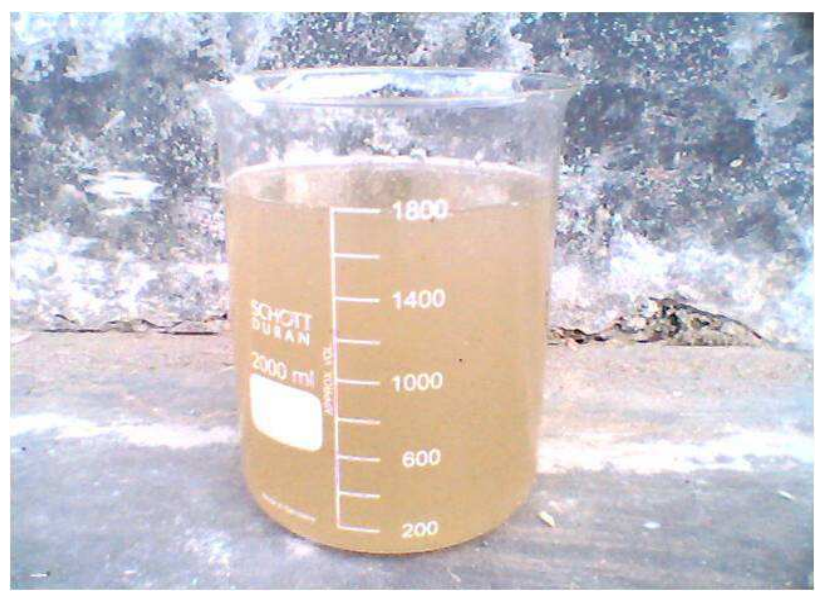

Fig. 3. Prepared Mucilage substances collected from ladies finger.
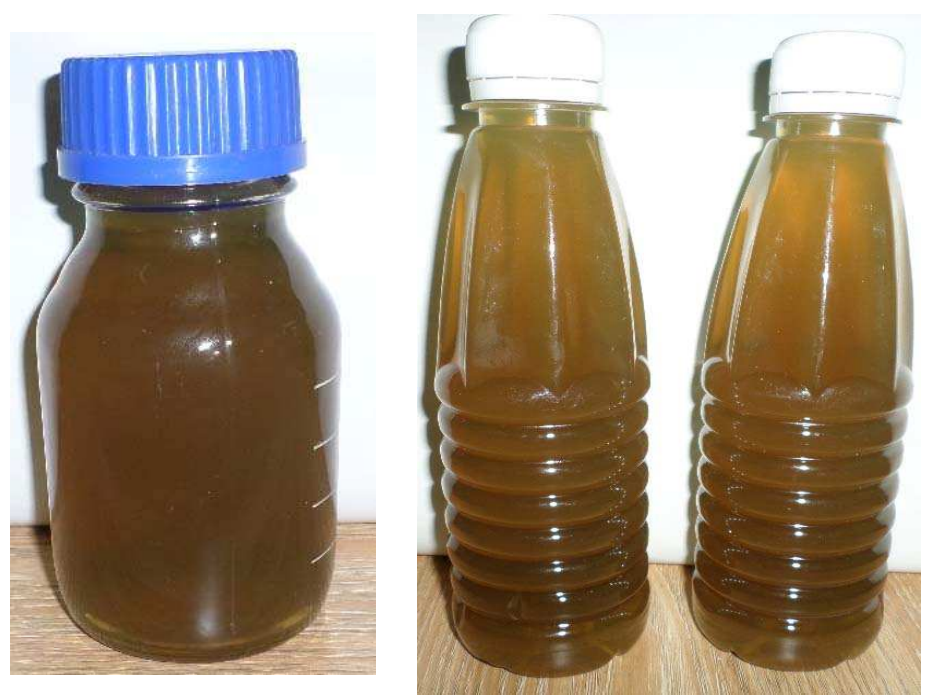

Fig. 5. Preserved sugarcane juice in glass and plastic bottles after four months. collect the juice using a hand crusher.

38, Isd 39 and Isd 40 were used. 11 months aged canes were collected from the field. Then they were washed and

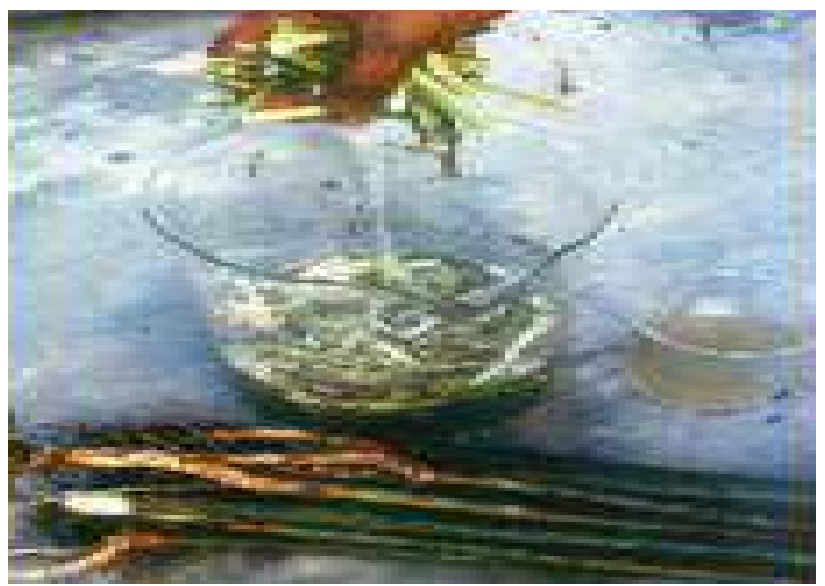

Fig. 2. Mucilage substances collected from ladies finger.

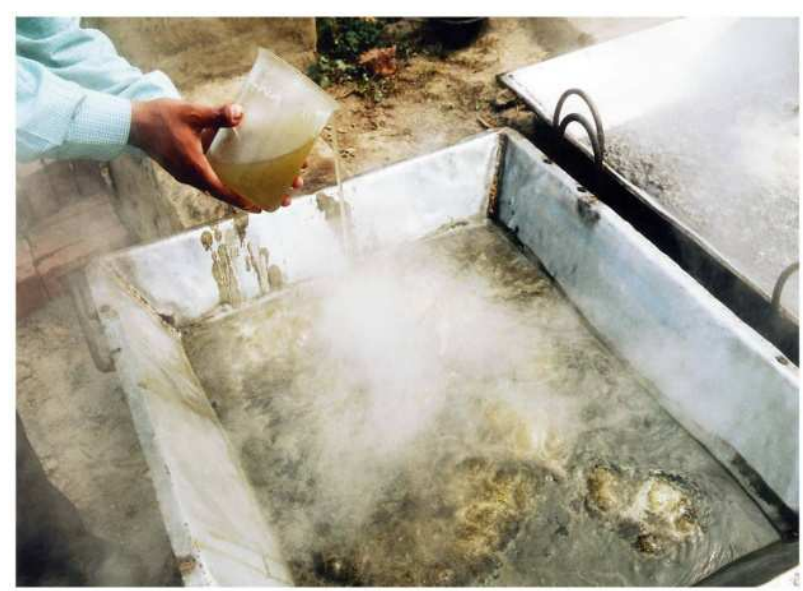

Fig. 4. Mixing the extract with boiling Juice. 


\subsection{Preparation of Ladies Finger Extract and Mixing into Juice}

First we collected the ladies finger plant. We cut the stem into pieces. Then we collect the outer layer of the stem and put into water for 30 minutes. Mucilage substances came out from stem and mixed with water. 250-300 gm extracts are used as clarificant for 180 liter sugarcane juice. Juices were then boiled at $100^{\circ} \mathrm{C}$ for 10 minutes. During boiling mucilage substances which were collected from ladies finger were mixed with juice. After mixing the extract all the dirty substances and fiber became clod together. Then we removed them completely. Thus we got a clear and transparent juice. Then the juices were bottled after cooling in germfree airtight bottles using laminar flow chamber and preserved for four months in room temperature $\left(25^{\circ} \mathrm{C}\right)$.

\subsection{Analysis the Juice Before and After Preservation}

Juices were analysed before preservation and every 15 days after one bottle were analyzed for determination of qualitative characters like bix, pol, purity, reducing sugar. Microbial tests were also done after every 15 days.

\subsection{Determination of Brix, Pol, Purity and Reducing Sugar}

Soluble solids ( ${ }^{\circ}$ Brix) was determined by Brix hydrometer standardized at $20^{\circ} \mathrm{C}$ and Horne's dry lead method was used for sucrose determination using an automatic polarimeter (Bellingham and Stanley ADP-220®). Juice purity was calculated as the ratio of the sucrose content and corrected Brix reading. Reducing sugars were determined by the method described in Queensland Laboratory Manual [Bureau Sugar Experiment Stations (BSES), 1970].

\subsection{Statistical Analysis}

The collected data for a character under certain treatment were calculated and statistically analyzed following Factorial Completely Randomized Design (CRD). The analysis of variance was performed and means were compared by Duncans New Multiple Range Test (DMRT) at $5 \%$ level of probability for interpretation of results.

\section{Results and Discussion}

\subsection{Difference Between the Fresh Juice and the Juice After Boiling with Clarificant}

Color of the fresh juice after collection were greenish but after boiling mixing with clarificant it became slightly reddish and brix percentage became increased $1-2 \%$.

\subsection{Qualitative Analysis Result Before and After Preservation}

Before preservation Varieties have significant effects on different qualitative parameters of cane juice. Highest pol (14.05) and purity (88.28) percentage and lowest reducing sugar percentage $(0.1833)$ were achieved in the variety Isd 38 followed by Isd 39 though it achieved highest brix percentage. The lowest brix (16.68), pol (11.56), purity percentage (84.98) and highest reducing sugar (0.5567) were observed by the variety Isd 34 (Table 1).

Table 1. Effects of varieties on different qualitative parameters of cane juice.

\begin{tabular}{|c|c|c|c|c|}
\hline $\begin{array}{l}\text { Name of } \\
\text { varieties }\end{array}$ & Brix & Pol & Purity & R. S. \\
\hline Isd $34\left(V_{1}\right)$ & $16.68 \mathrm{e}$ & $11.564 \mathrm{c}$ & $84.98 b$ & $0.5567 \mathrm{a}$ \\
\hline Isd $36\left(V_{2}\right)$ & $18.78 \mathrm{~d}$ & $12.588 \mathrm{~b}$ & $86.84 \mathrm{ab}$ & $0.4767 \mathrm{~b}$ \\
\hline Isd $37\left(V_{3}\right)$ & $19.73 \mathrm{c}$ & $13.487 \mathrm{a}$ & $86.10 \mathrm{ab}$ & $0.4150 \mathrm{c}$ \\
\hline $\operatorname{Isd} 38\left(V_{4}\right)$ & $20.19 \mathrm{~b}$ & $14.05 \mathrm{a}$ & $88.28 \mathrm{a}$ & 0.1833 \\
\hline Isd $39\left(V_{5}\right)$ & $20.42 \mathrm{a}$ & $14.02 \mathrm{a}$ & $87.36 \mathrm{a}$ & 0.2683 \\
\hline Isd $40\left(V_{6}\right)$ & $19.68 \mathrm{c}$ & $13.49 \mathrm{a}$ & $87.29 \mathrm{a}$ & $0.3800 \mathrm{~d}$ \\
\hline LSD $(5 \%)$ & 0.0640 & 0.7282 & 2.2615 & 0.0341 \\
\hline
\end{tabular}

Table 2. Effects of months on different qualitative parameters of cane juice.

\begin{tabular}{lllll}
\hline $\begin{array}{l}\text { Name of } \\
\text { months }\end{array}$ & Brix & Pol & Purity & R. S. \\
\hline $\begin{array}{l}\text { October }\left(\mathrm{M}_{1}\right) \\
\text { November }\end{array}$ & $19.17 \mathrm{c}$ & $13.10 \mathrm{~b}$ & $85.57 \mathrm{~b}$ & $0.4450 \mathrm{~b}$ \\
$\left(\mathrm{M}_{2}\right)$ & $20.08 \mathrm{~b}$ & $13.85 \mathrm{a}$ & $88.02 \mathrm{a}$ & $0.1983 \mathrm{~d}$ \\
December $\left(\mathrm{M}_{3}\right)$ & $18.48 \mathrm{f}$ & $12.47 \mathrm{~b}$ & $85.89 \mathrm{ab}$ & $0.6383 \mathrm{a}$ \\
January $\left(\mathrm{M}_{4}\right)$ & $18.85 \mathrm{e}$ & $12.85 \mathrm{~b}$ & $86.54 \mathrm{ab}$ & $0.2000 \mathrm{~d}$ \\
February $\left(\mathrm{M}_{5}\right)$ & $19.82 \mathrm{~b}$ & $13.93 \mathrm{a}$ & $87.48 \mathrm{ab}$ & $0.3300 \mathrm{c}$ \\
March $\left(\mathrm{M}_{6}\right)$ & $19.09 \mathrm{~d}$ & $13.01 \mathrm{~b}$ & $87.36 \mathrm{ab}$ & $0.4683 \mathrm{~b}$ \\
Lsd $(5 \%)$ & 0.0640 & 0.7282 & 2.2615 & 0.0341 \\
\hline
\end{tabular}

Different months have significant effects on different qualitative parameters of cane juice. Highest pol (13.93) was achieved in the month February followed by November (13.85). Highest brix (20.08), purity percentage (88.02) and lowest reducing sugar $(0.1983)$ were achieved in November (Table 2).

Interaction of variety with months have significant effects on different qualitative parameters of juice. Highest brix percentage was achieved by the variety Isd 40 in the month of February. In case of pol percentage highest level were achieved by the interaction of Isd 36 and Isd 39 with January, Isd 39, Isd 40 with the month of February and Isd 38 in the month of March. Highest purity percentage were observed by the varieties Isd 36 and Isd 40 in the month of October, Isd 34, Isd 36, Isd 39 and Isd 40 in the month of January Isd 38 in the month of February and March and Isd 39 in the March. Lowest reducing sugar was observed in Isd36 in the month of January and Isd 38 in the month of March. 
Table 3. Interaction effects of Varieties $x$ Months.

\begin{tabular}{|c|c|c|c|c|}
\hline Varieties X Months & Brix & Pol & Purity & R. S. \\
\hline $\mathrm{V}_{1} \mathrm{M}_{1}$ & $15.5 \mathrm{~s}$ & $9.98 \mathrm{k}$ & $82.58 \mathrm{bcd}$ & $0.72 \mathrm{~b}$ \\
\hline $\mathrm{V}_{2} \mathrm{M}_{1}$ & $19.4 \mathrm{j}$ & $13.42 \mathrm{a}-\mathrm{h}$ & $88.71 \mathrm{a}$ & 0.35 fghd \\
\hline $\mathrm{V}_{3} \mathrm{M}_{1}$ & $16.2 \mathrm{r}$ & $10.80 \mathrm{jk}$ & 84.94 abcd & $0.66 \mathrm{bc}$ \\
\hline $\mathrm{V}_{4} \mathrm{M}_{1}$ & $15.2 \mathrm{t}$ & $9.58 \mathrm{k}$ & $80.26 \mathrm{~d}$ & $0.38 \mathrm{efg}$ \\
\hline $\mathrm{V}_{5} \mathrm{M}_{1}$ & $16.9 \mathrm{q}$ & $11.14 \mathrm{i}-\mathrm{k}$ & 84.50 abcd & $0.58 \mathrm{c}$ \\
\hline $\mathrm{V}_{6} \mathrm{M}_{1}$ & $16.9 \mathrm{q}$ & $11.13 \mathrm{i}-\mathrm{k}$ & $88.91 \mathrm{a}$ & $0.65 \mathrm{bc}$ \\
\hline $\mathrm{V}_{1} \mathrm{M}_{2}$ & $19.1 \mathrm{kl}$ & $13.11 \mathrm{a}-\mathrm{h}$ & $86.34 \mathrm{ab}$ & $0.59 \mathrm{~cd}$ \\
\hline $\mathrm{V}_{2} \mathrm{M}_{2}$ & $19.8 \mathrm{~h}$ & $13.67 \mathrm{a}-\mathrm{g}$ & $87.93 \mathrm{ab}$ & $0.30 \mathrm{gh}$ \\
\hline $\mathrm{V}_{3} \mathrm{M}_{2}$ & $17.5 \mathrm{p}$ & $11.80 \mathrm{~h}-\mathrm{j}$ & $85.89 \mathrm{abc}$ & $0.60 \mathrm{~cd}$ \\
\hline $\mathrm{V}_{4} \mathrm{M}_{2}$ & $18.5 \mathrm{n}$ & $12.65 \mathrm{~d}-\mathrm{i}$ & $87.08 \mathrm{ab}$ & $0.30 \mathrm{gh}$ \\
\hline $\mathrm{V}_{5} \mathrm{M}_{2}$ & $19.5 \mathrm{ij}$ & $11.91 \mathrm{~g}-\mathrm{j}$ & $87.23 \mathrm{ab}$ & $0.44 \mathrm{e}$ \\
\hline $\mathrm{V}_{6} \mathrm{M}_{2}$ & $18.3 \mathrm{o}$ & $12.39 \mathrm{e}-\mathrm{j}$ & $86.58 \mathrm{ab}$ & $0.63 \mathrm{c}$ \\
\hline $\mathrm{V}_{1} \mathrm{M}_{3}$ & $20.0 \mathrm{~g}$ & $13.71 \mathrm{a}-\mathrm{f}$ & $80.50 \mathrm{~cd}$ & $0.54 \mathrm{~d}$ \\
\hline $\mathrm{V}_{2} \mathrm{M}_{3}$ & $20.1 \mathrm{fg}$ & $13.66 \mathrm{a}-\mathrm{g}$ & $87.36 \mathrm{ab}$ & $0.18 \mathrm{jk}$ \\
\hline $\mathrm{V}_{3} \mathrm{M}_{3}$ & $19.6 \mathrm{i}$ & $13.35 \mathrm{a}-\mathrm{h}$ & $86.79 \mathrm{ab}$ & $0.54 \mathrm{~d}$ \\
\hline $\mathrm{V}_{4} \mathrm{M}_{3}$ & $19.5 \mathrm{ij}$ & $13.31 \mathrm{a}-\mathrm{h}$ & $86.97 \mathrm{ab}$ & $0.27 \mathrm{hi}$ \\
\hline $\mathrm{V}_{5} \mathrm{M}_{3}$ & $20.0 \mathrm{~g}$ & 13.79 a-f & $87.85 \mathrm{ab}$ & 0.43 ef \\
\hline $\mathrm{V}_{6} \mathrm{M}_{3}$ & $19.2 \mathrm{k}$ & $13.10 \mathrm{a}-\mathrm{h}$ & $87.15 \mathrm{ab}$ & $0.53 \mathrm{~d}$ \\
\hline $\mathrm{V}_{1} \mathrm{M}_{4}$ & $20.2 \mathrm{f}$ & 14.02 a-f & $88.52 \mathrm{a}$ & $0.33 \mathrm{gh}$ \\
\hline $\mathrm{V}_{2} \mathrm{M}_{4}$ & $21.0 \mathrm{bc}$ & $14.76 \mathrm{a}$ & $89.40 \mathrm{a}$ & $0.07 \mathrm{~m}$ \\
\hline $\mathrm{V}_{3} \mathrm{M}_{4}$ & $20.1 \mathrm{fg}$ & 13.82 a-f & $87.56 \mathrm{ab}$ & $0.27 \mathrm{hi}$ \\
\hline $\mathrm{V}_{4} \mathrm{M}_{4}$ & $19.0 \mathrm{~lm}$ & 13.00 a-h & $87.16 \mathrm{ab}$ & $0.08 \mathrm{~lm}$ \\
\hline $\mathrm{V}_{5} \mathrm{M}_{4}$ & $20.9 \mathrm{c}$ & $14.60 \mathrm{a}$ & $88.87 \mathrm{a}$ & $0.15 \mathrm{jklm}$ \\
\hline $\mathrm{V}_{6} \mathrm{M}_{4}$ & $20.5 \mathrm{e}$ & 14.08 a-e & 88.19 a & $0.20 \mathrm{ij}$ \\
\hline $\mathrm{V}_{1} \mathrm{M}_{5}$ & $20.7 \mathrm{~d}$ & $14.33 \mathrm{a}-\mathrm{d}$ & $87.84 \mathrm{ab}$ & $0.15 \mathrm{jklm}$ \\
\hline $\mathrm{V}_{2} \mathrm{M}_{5}$ & $20.2 \mathrm{f}$ & 13.77 a-f & $86.83 \mathrm{ab}$ & $0.15 \mathrm{jklm}$ \\
\hline $\mathrm{V}_{3} \mathrm{M}_{5}$ & $19.0 \mathrm{~lm}$ & $12.76 \mathrm{~b}-\mathrm{i}$ & $85.53 \mathrm{abcd}$ & $0.87 \mathrm{a}$ \\
\hline $\mathrm{V}_{4} \mathrm{M}_{5}$ & $20.2 \mathrm{f}$ & $14.01 \mathrm{a}-\mathrm{f}$ & $88.37 \mathrm{a}$ & $0.10 \mathrm{klm}$ \\
\hline $\mathrm{V}_{5} \mathrm{M}_{5}$ & $21.1 \mathrm{~b}$ & $14.59 \mathrm{a}$ & $87.98 \mathrm{ab}$ & $0.18 \mathrm{jk}$ \\
\hline $\mathrm{V}_{6} \mathrm{M}_{5}$ & $21.3 \mathrm{a}$ & $14.65 \mathrm{a}$ & $87.61 \mathrm{ab}$ & $0.16 \mathrm{jkl}$ \\
\hline $\mathrm{V}_{1} \mathrm{M}_{6}$ & $19.5 \mathrm{ij}$ & $13.42 \mathrm{a}-\mathrm{h}$ & $87.64 \mathrm{ab}$ & $0.34 \mathrm{gh}$ \\
\hline $\mathrm{V}_{2} \mathrm{M}_{6}$ & $20.0 \mathrm{~g}$ & 13.80 a-f & $87.90 \mathrm{ab}$ & $0.14 \mathrm{jklm}$ \\
\hline $\mathrm{V}_{3} \mathrm{M}_{6}$ & $18.5 \mathrm{n}$ & $12.29 \mathrm{f}-\mathrm{j}$ & 84.65 abcd & $0.89 \mathrm{a}$ \\
\hline $\mathrm{V}_{4} \mathrm{M}_{6}$ & $20.7 \mathrm{~d}$ & $14.52 \mathrm{a}$ & $89.37 \mathrm{a}$ & $0.07 \mathrm{~m}$ \\
\hline $\mathrm{V}_{5} \mathrm{M}_{6}$ & $20.5 \mathrm{e}$ & $14.22 \mathrm{a}-\mathrm{d}$ & $88.47 \mathrm{a}$ & $0.20 \mathrm{ij}$ \\
\hline $\mathrm{V}_{6} \mathrm{M}_{6}$ & $18.9 \mathrm{~m}$ & $12.69 \mathrm{c}-\mathrm{i}$ & 85.69 abcd & $0.64 \mathrm{bc}$ \\
\hline LSD (5\%) & 0.1567 & 1.7836 & 5.5395 & 0.0835 \\
\hline
\end{tabular}

Lower level of pol percentage and higher level of reducing sugars (simple sugar) were observed in juice collected from the varieties Isd 34, Isd 37, Isd 38, Isd 39 and Isd 40 in the month of October and November. Higher pol\% and lower reducing sugar was observed in Isd 36 from the month of October to March. Same trend was observed in varieties Isd 34 from the month of November to March. Preserved juice collected from variety Isd 36 in October to March and from varieties Isd 34, Isd 36 in November to March was lasted for four months. All the varieties showed higher pol percent and lower reducing sugar in the month of December to March. Preserved juice became spoiled within one week after preservation where comparatively lower pol percentage and higher reducing sugar were observed.

Results of qualitative parameter remain same after four months for juices which were preserved in the month from December to march. Preserved juices were also free from any microbial contamination.

High temperature, high humidity and rainfall are responsible for spoiling the cane juice. In Bangladesh temperature and humidity began to fall from October. In the month of December and January Lowest temperature and humidity was observed. If we preserved juice in December and January it will lasting for four months without deteriorating its quality because sucrose cannot convert into reducing sugar due to low temperature. Sucrose itself a good preservative and preservation capacity of sucrose is better than other monosaccharide like glucose and fructose which are known as reducing sugar. The reducing sugars in juice are an important indicator of cane deterioration (Uppal and Sharma, 1997; Magdum et al., 1987; Ahmad and Khan, 1988; Gaur and Desai, 1988). Bhatia et al., (2009) have reported a gradual increase in titrable acidity with parallel decline in $\mathrm{pH}$ of juice was also observed in all the genotype during storage (Bhatia et al., 2009). However, this effect was more pronounced during late crushing period i.e. at high temperature as reported by Mao et el., 2006. Uppal et al., (2006) have also observed decreasing trend of purity coefficient with increasing storage periods. Steel and Trost (2006) reported that the presence of bacteria reduced the sugar purity, which may be another reason for reduction of purity. The ambient temperature rises beyond $35^{\circ} \mathrm{C}$, and then a water soluble polymer of glucose (dextran) is synthesized from the stored sucrose. The dextran content in stale cane juice increased sharply with increase in dextransucrase activity. An enzyme extracellularly secreted by Leuconostoc bacteria present in rhizophere. The cut ends of the harvested cane facilitates invasion of microbes, particularly Leuconostoc bacteria inside cane, which converts stored sucrose into dextran through dextransucrase enzyme (Kin and Robyt, 1995). Luzio and Mayer (1983) reported that dextransucrase catalysed the hydrolysis of the substrate (sucrose) and that a glucosylated enzyme had three competing activities, hydrolysis, D- glucosyl transfer and polymerization. This enzyme secreted mostly by Leuconostoc bacteria, not only catalyses dextran synthesis from sucrose, but in the presence of other carbohydrates such as glucose, fructose also transfer glucose from the sucrose molecule to form oligosaccharides such as Leucrose and Palatinose (Robyt, 1995; Robyt and Eklund, 1982) and therefore, is a potential criteria for juice deterioration (Eggleston and Legendre, 2003). Through boiling the juice at $100^{\circ} \mathrm{C}$ for ten minutes, can reduced bacterial activities.

Considering the different factors juice collected from different varieties in the month of December and January showed higher lasting period using mucilage substance of ladies finger as clarificant.

\section{References}

[1] Ahmad R, Khan A.Q., (1988) Effect of post-harvest cane staling in winter and summer on drainage and quality characters in sugarcane. Proc Ann Conv Sugar Tech Assoc India, 51:155-168

[2] Bhatia S., Jyoti, Uppal S.K., Thind K.S., Batta S.K. (2009) Postharvest quality deterioration in sugarcane under differentenvironmental conditions. Sugar Tech 11(2):154-160

[3] Banerji R., Madan V.K., Misra S. R. (1997). Preservation of sugarcane juice, Indian sugar, 47(3), 195-200. 
[4] Bureau Sugar Experiment Stations (BSES) (1970). Laboratory Manual for Queensland Sugar Mills (5th Ed.), Division of Mill technology, Brisbane, Queensland, Australia, 5: $95-98$ and pp.113-114

[5] Eggleston G., Legendre B.L. (2003). Mannitol and oligosaccharides as new criteria for determining cold tolerance in sugarcane varieties. Food Chem 80:451-461

[6] Gaur S.L., Desai B. (1988) Influence of storage on postharvest deterioration of juice quality in some promising co varieties of Sugarcane. J Maharastra Agric Univ 13(2):120131

[7] Kin D., Robyt J.F. (1995). Production, selection and characterization of mutants of Leuconostoc mesenteroides B742. Constitutive of dextransucrase, Enzyme Microbiol Technol 17:689-695

[8] Krishnakumar T. and Devadas C.T. (2006).Microbiological changes during storage of sugarcane juice in different packing materials, Beverage \& Food World 42(4), 82-83.

[9] Swaminathan V. (1995). Food Science Chemistry\& Experimental Foods, the Bangalore Printing \& Publishing Co. ltd., Bagtalore

[10] Luzio G.A., Mayer R.M. (1983). Carbohydr Res III, 311

[11] Magdum D.N., Kadam S.K., Patil M.D. (1987). Post-harvest deterioration of sugarcane under different storage condition and consequent losses. Cooperative Sugar 18(7):453-460

[12] Mao L., Que F., Wang G. (2006). Sugar metabolism and involvement of enzymes in sugarcane (Saccharum officinarum L.) stems during storage. Food Chem 98:338- 342
[13] Phanikumar H.K. (2011). Sugarcane juice powder by spray drying technique, Science Tech Enterpreneur, National Research Development Corporation (An Enterprise of DSIR, Min. of S\&T, Government of India), Malleswaram, Bengaluru.

[14] Parvathy K., Bottiling of Sugarcane juice, proceedings of the schemes of studies on harvest \& post harvest technology (ICAR), Coimbatore Center, Annual Report, Feb 1983, 13-16

[15] Robyt J.F., Eklund S.H. (1982). Steriochemistry involved in the mechanism of action of dextransucrase in the synthesis of dextran and the formation of accepter products. Biorg Chem 11:115-132.

[16] Robyt J.F. (1995). Mechanisms in the glucansucrose synthesis of polysaccharides and oligosaccharides from sucrose. Advances in carbohydrates Chemistry and Biochemistry 51:133-168

[17] Steel F.M., Trost L.W. (2006) Control of microbiological losses prior to cane delivery during sugar processing. Int. Sugar J (UK) 104:118-123

[18] Uppal S.K. and Sharma K.P., (1997). Post-harvest loss in cane weight and formation of mollasogenic sugar in sugarcane on staling during weather months. Cooperative Sugar 29:172-174.

[19] Uppal S.K., Bhatia S., Thind K.S. (2006) Methods of cane preparation for milling and their effect on post-harvest sucrose losses in sugarcane. Proc Internl Symp On Technologies to Improve Sugar Productivity in Developing Countries, Guilin, P R China, p 422-425. 